UDC 316

Kristine TANAJYAN

\title{
CIVIL SOCIETY AS AN AREA OF A PERSONALITY SELF-REALIZATION
}

\begin{abstract}
In this article we will discuss the mechanisms of self-realization, and civil duties. The author considers the civic society as a socio-cultrural field for effective self-realization. From this point of view, self-realization can be considered as a skill of creative discovery of truth and social justice. Through self-realization a person can gain self-determination - socially, culturally and historically. This paper overviews several mechanisms for realization in Civic society. Civic society supposes protection and acceptance of human rights and freedoms. It creates conditions for manifestation of a person and self-realization, providing the person's active and responsible participation in social processes. Self-realization is a reproductive and identity specification mechanism of a person.
\end{abstract}

Keywords: civil society, subject of social activity, self-existence, self-realization, mechanisms of self- realization, types of self-realization.

Person-society is an eternal issue. Any person being a social structural element is formulated by social features, skills and qualities.

Concurrent to changes of social environment, a person also changes, acquires a certain group of features and affecting on social environment, changes both oneself and the environment.

Shakespeare said: "Life is a multilayered theatrical play, where the person is the bearer of social roles, the player, the audience and the expert". "Staged society" phrase perfectly expresses the essence of today's society.

Today a person appears more as a social governing active subject, as creator and consumer of material and spiritual values. On the other hand, people, masses, nations, peoples, states keen to be acknowledged, overcome inferiority and vulnerability. For gainful so- lutions to such issues in social constructive level, corresponding self stage is needed and today the civic society can be the one.

Civil society is one of the most important value and culture-forming phenomena of modern society. Civil society in its generally accepted sense, acts as a set of social formations (groups or teams), joined together by specific interests (economic, ethnic, cultural, etc.), implemented beyond the government activity area and allowing, in conditions of a democratic system of social life arrangement, to control actions of state authorities as hierarchies of power and political institutions.

Civil society is a sphere of public activity, free from the direct influence of the state and its officials.

Civic society supposes protection and acceptance of human rights and freedoms. It creates conditions for manifestation of a per- 
son and self-realization, providing the person's active and responsible participation in social processes.

In social-philosophical point of view, person's realization supposes display of hidden potential of person's mental, socialpsychological, characteristic features and qualities. Self-realization is displayed in satisfaction of self-existence.

In one overview, Mortimer Adler defines self-realization as freedom from external coercion, including cultural expectations, political and economic freedom, and the freedom from worldly attachments and desires etc (Adler, 1995, pp. 137-138).

A number of ways of person's self-realization can be pointed out, each of which provide favorable conditions for productive process of social society principles. Traditional mean of self-realization is formation of social-economic status, which is an ongoing process in person's socialization progression. In this point, definition of civil society as liberal, democratic, legal one becomes primary, where the person is principle and axis with its private interests, needs and expectations. A person can be relatively free only in case of possessing own life resources. Incontestably, the civil society is connected to the development of private resources, which became stimulus for a person's creative activity and interest in industry development.

Generally, we differentiate several mechanisms for realization private interests, needs and expectations:

- Through violation of other's interests, which is Social Parasitism,

- Through mutual beneficial cooperation, in other words Target Sinergie,
- Through principle of voluntary implementation of other's interests, that is Social Altruism.

Taking into consideration the mentioned above, we must remember that individual interest is not the impetus for the society; it becomes one only when the interest of the whole coincides.

Civil society is a human political-social lifestyle, unity of civilians, within the frames of which each individual is interested in providing dignified life for everyone, and each civilian realizes his/her political activity, interests, satisfies natural needs and social interests (Konoplin \& Nagayeva , 2008, p. 51). In modern world, prevailing opportunities of manifestation and self-realization of a person are in economic field. And in case of effective functioning conditions of the civil society, a person has positive self-realization and social development guarantees in economic field.

Each person has a right to use own abilities in civil society, including entrepreneurship and other economic activities allowed by law, which supposes free market development (Orlova, 2005, p. 22), due to person's social activity.

In traditional societies interests of individuals obtain political definition and provide high level of person's self- realization. The developed the civil society the harder the construction in means of interests and their realization mechanisms. In order to act gainfully in civil society, it is important for the person to be distinguished as politically active and ideally open person. Civil society requires a certain political environment where individuals are free to discuss and associate in the first place. It likewise shows that socioeconomic 
development is highly advantageous to nations attempting to build a strong Western style democracy (Putnam and the Civil Society Ian Fasel).

We can say that the civil society's economic, spiritual, moral conditions of life is a unique group, which promotes individual benefit, realization of interests, active increase of economic, political, cultural fields. We can say that the civil society is a unique combination of economic, religious, and moral aspects of life, which contributes to private benefit, realization of interests of a person's activity in economic, political and cultural spheres.

In this point of view, self-realization can be considered as a skill of discovering the truth creatively and social justice. Through self-realization a person can self-determinate socially, culturally and historically. Selfrealization is a reproductive and identity specification mechanism of a person.

Types of person's self-realization also varies, according to activity fields, there are scientific, religious, economic, legal-political, etc... By choosing this or that field for selfrealization a person seeks possibilities (Tsvetkova, 2008, p. 147) for solving important problems of own self in certain historical and social periods of time. In such social-historical conditions a unique way for self-realization becomes strong social bonds and enlarged circle of social relationships. From this point of view bridged social capital is important, as an additional opportunity of selfrealization.

Social capital is an effort resource of institutionally based social relationships chain in certain historical time, which benefits the existence of the best option of social system. Despite other types of a capital, social capital is a construction of role players and their relationships. Attribute of that system is to provide participants with wellness (Burt, 1992. p. 45).

On one hand civil society offers real premises and equipments for person's selfrealization and creation, on the other hand a person with its creative impact and innovative aspiration consolidates civil society's organizing ideas, becoming the guarantor of legitimacy of authorities. In civil society's conditions, belief towards legitimate authorities strengthens, as each person achieves legal status in any sub-system of the society for equal self-realization, despite free social, domestic, professional, doctrinal and other statuses

In $21^{\text {st }}$ century, more frequent way of self-realization is constant search and change of work and activity fields. This can be a reason of lack of institutional trust, as well as interchange of social-cultural high-speed processes in post-transitional societies. Selfrealization of a person can be observed as focused effort of person's potential. And focused efforts are fed from inner and outer reasons of self-realization. If person's inner selfrealization reasons are the demands and interests of an individual, which are defined as orientations in civil society, then outer reasons are person's tendency to freedom and social activity level, which are reinforced and stabilized through civil society. In this regard, we should note that the civil society primarily is a society of free people, where the civil freedom is guaranteed by law in all its senses. And the latter is a necessary condition for person's perfection, as a guarantor of person's dignity uphold. More than that, a person is an owner here, who has an opportunity to choose the form of ownership and dispose it. And 
property is an existence of freedom (Gegel, 1934, pp. 72-73).

- Liberated owner is the constructive cornerstone of democratic regime. Hence, the civil society is the field of expressing person's social, political, cultural essence, constructive field for its selfrealization, self-assertion. Freedom of ability manifestation of a person is guaranteed here, as well as freedom of choice of activity type and professional selection.

- From this point of view, we should note that the civil society is a collective form of person's dignified relationships and lifestyle. Civil society, based on a person's specifications, gives an opportunity to have a feeling of satisfaction for own achievements.

In this sense, we must note that civil society first of all is a society of liberal people, where civil freedom is lawfully protected in all its manifestations. And the latter is an important component for person's perfection as a guarantee of preservation of human dignity. Moreover, a person is the owner, who has a chance to choose the form of ownership and direct it. And ownership is the existence (Gegel, 1934, pp. 72-73) of availability of accommodation. That is to say, liberalism is not a backbone democratic value (Harutyunyan, 2003, pp. 8-9).

It can become such through active political participation of civilians and through selfrealization in their demanding actions in political system. From this point of view Joohn Locke discusses many ideas that are now attributed to Liberalism in Two Treatises of Government (1689). Locke comments on society and outlines the importance of natural rights and laws. He believes that people are born as blank slates without any preordained ideas or notions. This state is known as the State of Nature because it shows people in their most barbaric form. As people grow, their experiences begin to shape their thoughts and actions. They are naturally in the State of Nature until they choose not to be, until something changes their barbaric nature ${ }^{1}$.

As Aristoles says: "The truth is that men's ambition and their desire to make money are among the most frequent causes of deliberate acts of injustice."

But Locke says that, civil government can remedy this anarchy. When it comes to the Law of Nature, people are more likely to act rationally when there is a government in place because there are laws and consequences to abide by. It should be noted that person's political self-realization supposes conscious and pressure of law and "brutal" displays of liberalism under legal patronage.

From this point of view, purpose of civil society in Armenia is not realized, more than that, its realization is still but an unclear mirage. Turning that mirage to reality is due to accepting a human being as the highest value.

And in our reality a person's value measured with its blood or relative ties, position in social system. In other words, a person is valued not as being human, but as a connection complex, whose activity range is nepotism. The only way for pressuring and denial of abnormal nepotism in our society is through considering political activity of legally conscious people as propulsive force of self-realization.

1 See: https://en.wikipedia.org/wiki/Liberalism (international_relations) 
Surely, not everyone achieve complete self-realization, but the upbringing of the will, developing ambitions to innovations and creativity are the very ways which lead to selfrealization of a person. And the bases of uncovering those ways are in the family. Family is undoubtedly mandatory for civil society. We must note that a family can be the primary and major stage for self-realization, making self-determination and self-realization possible, if a person holds the stamp of civil society features, especially if his/hers human rights and freedoms are protected in inner-family relationships and is provided with quality aspects of social development.

Most important features of a person in civil society must be tolerance and social justice. The heart of tolerance is self-control. When we tolerate an activity, we resist our urge to forcefully prohibit the expression of activities that we find unpleasant. More abstractly, toleration can be understood as a political practice aiming at neutrality, objectivity, or fairness on the part of political agents.

These ideas are related in that the goal of political neutrality is deliberate restraint of the power that political authorities have to negate the life activities of its citizens and subjects. Related to toleration is the virtue of tolerance, which can be defined as a tendency toward toleration. Toleration is usually grounded upon an assumption about the importance of the autonomy of individuals. This assumption and the idea of toleration are central ideas in modern liberal theory and practice ${ }^{2}$.

Person-civil-society relationships are ambiguous and bipolar.

Behavior of civilians must be led with

2 See: http://www.iep.utm.edu/tolerati such features as self-organization, self-reliance and self-responsibility. The civil society with its values, basic aspects and guarantee of human rights and freedoms, benefits creation of all ways for self-realization of a person.

As a rule, non-compliance, social inequality and social injustice in traditional and close societies prevent the self-realization horizon of a person and become a reason for a number of crises. Result of a crisis is more tragic, especially in spiritual-cultural field of the society.

Meanwhile, results of positive selfrealization are disposed by high level of selfrespect, social construction of consciousness of own self, forth bringing of altruistic interests and aims and activation of searches their solutions by accepting both own and others' freedom, meaningful with purposeful and aimed actions.

Self-realization of a person is construction and realization of a person's development opportunities; certain historical time and public management regime have their direct impact on the choice of means of person's selfrealization. The latter can be observed as a way of expression, development and perfection of person's efforts. In this regard, it is obvious that in civil society, person's selfrealization process depends on people's legal conscious, focused efforts that result from the level of stability of civic identity

Self-realization of a person depends both on terms of use of freedom and justice in the society and clarification of aims of social structures, information level of wide strips of the society and social structures and cultivation of legal guarantees of civilians' cooperation. 
Level of a person's self-realization is measured by the level of satisfaction by own actions, number of their deeds and frequency of responses social issues.

\section{REFERENCES}

Burt, R. (1992) Structural Holes: The Social Structure of Competition. Cambridge: Harvard University Press.

Frank, S.L. (1992) Dukhovnaya osnova obshchestva: Vvedenie $v$ sotsial'nuyu psikhologiyu (Spiritual bases of society: Introduction of social psychology, in Russian). Moscow.

Goncharov, D.V., \& Goptareva, I. (1996). Vvedenie v politicheskuyu nauku (Introduction of Political Science, in Russian). Moscow: Yurist.

Harutyunyan, E.A. (2003). Qaghaqakan hamakargi zargacman himnaxndirnery' ancumayin hasarakut'yunum (Main Issues in Political System in Transitional Societies, in Armenian). Yerevan.
Hegel. (1934), Sochineniya (Works, in Russian).Vol. 7. Moscow.

Konoplin, Y.S., \& Nagaeva, S.K. (2008). Grazhdanskoe obshchestvo v politicheskom izmerenii (Civil Society in Political Dimension, in Russian). Moscow.

Mortimer, J.A. (1995). Liberty.

Orlova, O.V. (2005) Grazhdanskoe obshchestvo i lichnost': politico-pravovye aspekty (Civil society and an individual: political-legal aspects, in Russian). Moscow.

Putnam and the Civil Society http://www.la.utexas.edu/users/chenr $\mathrm{y} /$ civil/archives99/csspapers/0022.ht $\underline{\mathrm{ml}}$.

Sektova, N.A. (2011). Sotsial'nyi intellekt kak determinanta urovnya samorealizatsii lichnosti $v$ professional'noi deyatel'nosti (Social intellect as a determinate of self-realization level and professional activity, in Russian) Humanitarian vector. N1 (25). 